Research Article

\title{
AN ANALYSIS OF CONTRIBUTION FROM HOTEL AND RESTAURANT TAXES TO MANADO CITY DISTRICT OWN REVENUE
}

\author{
Anita Ludia Vivian Wauran \\ Politeknik Negeri Manado, Indonesia
}

\section{Article history:}

Submission 28 August 2020

Revised 23 September 2020

Accepted 19 December 2020

${ }^{*}$ Corresponding author:

E-mail: anitaludia@gmail.com

\begin{abstract}
One of the efforts in financing regional development is to increase regional income sourced from regional taxes. The Manado City Government in carrying out the effort to increase the regional tax is carried out by the Regional Tax and Retribution Management Agency as a place to carry out the Regional Government's authority in the context of decentralization in the area of regional income, especially in the area of Manado's local tax. The source of revenue from District Own Search Revenue of Manado City comes from local taxes, such as hotel taxes, restaurants, entertainment, billboards, parking, water and land taxes, swallow nests, Land and Building taxes P2, BPHTB, PLN and Non PLN Street lighting taxes, minerals non metal and rock. This research aims to find out how much the contribution of hotel and restaurant taxes can be generated as District Own Search Revenue with the growth of tourism that continues to increase coupled with the growth of hotels and restaurants in Manado City, with the benefits of the research is expected to provide input to the Manado City government in efforts to increase District Own Search Revenue through hotel and restaurant taxes. This research uses a contribution analysis, with the average contribution of hotel and restaurant tax realization to District Own Search Revenue per year of $7.06 \%$ and the level of effectiveness of hotel and restaurant taxes running fluctuations from year to year
\end{abstract}

Keywords: Contributions, Hotel, Restaurant, Taxes, Revenue

\section{Introduction}

Own Source Revenue (OSR), Law of the Republic Indonesia number 33 of 2004, consists of: (1) Local Tax yields, (2) Results of regional levies, (3) Results of regionally owned companies and separated regional wealth management results, and (4) Other own sourcee revenue. OSR is a own source revenue that can be freely used by each region to organize regional government and development. With the presence of regional autonomy, regions are encouraged to be able to be creative in looking for regional revenue sources that can support the financing of regional government expenditures or expenditures in order to carry out government and regional development tasks.

One source of Revenue is derived from local taxes. Local Taxes are taxes collected by the Regional Government and used by the regions for the benefit of household financing of the regional government. Local taxes are one of the

\section{How to cite:}

Wauran, A. L. V. (2020). An Analysis of Contribution from Hotel and Restaurant Taxes to Manado City District Own Revenue. Indonesian Journal of Social Science Research, 1 (1), 10- 18. doi: 10.11594/ijssr.01.01.02 
sources of OSR that are expected to be able to provide a large contribution to the region itself so as to facilitate the administration of the government and regional development.

The city of Manado is one of the cities in the province of North Sulawesi whose regional governments always strive to increase their regional income from year to year in accordance with established policies from both the central government and the North Sulawesi province. Manado City's Own Source Revenue is divided into 4 parts, Local Taxes, Regional Levies, Separate Regional Wealth Management Results, and others Legitimate Local Revenue.

One of the regional taxes whose potential is growing along with the increasing attention of the supporting components, namely the service sector and tourism in regional development policies is the hotel tax and restaurant tax. Given that the city of Manado has a fairly com- plete tourist attraction both coastal and mountainous tourism, so the taxes extracted from the hotel and restaurant sector are quite high.

By separating the type of restaurant tax from hotel and restaurant taxes that it affects the decrease in contribution to local revenue. Based on Manado City Regional Regulation No.2 of 2011 concerning Development Taxes, Hotel Taxes are taxes on services provided by hotels. Where as restaurant taxes are taxes on services provided by restaurants. In addition, based on the author's observation that the establishment of hotels and restaurants around tourist areas as well as in tourist objects in the city of Manado can have a positive impact on the receipt of Own Source Revenue (OSR). As for the development of Manado City's Own source Revenue, Realization of Hotel and Restaurant Taxes and the number of hotels and restaurants in Manado City in Table 1 below:

Table 1. Own-Source Revenue of Manado City, Realization of Hotel Taxes and Restaurants and the total of hotels and restaurants in Manado City

\begin{tabular}{cccccc}
\hline \multirow{2}{*}{ Year } & \multicolumn{2}{c}{ Tax Realization } & OSR & \multicolumn{2}{c}{ Total } \\
\cline { 2 - 6 } & Hotel & Restaurant & & Htl. & Rst. \\
\hline 2014 & 17.449 .408 .116 & 40.401 .504 .799 & 263.392 .296 .958 & 104 & 98 \\
\hline 2015 & 18.168 .799 .451 & 47.469 .492 .846 & 289.462 .741 .463 & 125 & 79 \\
\hline 2016 & 25.425 .453 .862 & 60.607 .630 .932 & 306.453 .382 .648 & 157 & 142 \\
\hline \multicolumn{2}{c}{ Source: BP2T (2018) } & & & &
\end{tabular}

Based on Table 1 above, it can be seen in 2014 to 2016 the realization of hotel taxes fluctuated while restaurant taxes always increased. In 2014 to 2016 the Own Source Revenue of the City of Manado always increased. The number of hotels always increases and the number of restaurants in Manado City fluctuates.

The concern is that the hotel and restaurant sector only contribute to Manado City's Own Source Revenue (OSR) by $7.06 \%$ per year for hotel taxes and $17.22 \%$ per year for restaurant taxes. Based on the potential of Manado City, the government can actually increase the realization of hotel and restaurant taxes. Therefore, researchers tried to conduct research on hotel tax receipts and restaurant taxes in the city of Manado and how much they contributed to Own Source Revenue in the City of Manado.

Based on the background of the problems described previously, the problem formulation is how to analyze the contribution of Hotel Tax and Restaurant Tax to the receipt of Own Source Revenue (OSR) in Manado City, the purpose of this study is to determine the effectiveness and analysis of hotel tax and restaurant tax on receipts of Own Source Revenue Manado City. Hotel tax is a tax on services provided by the hotel. Understanding of hotels here includes lodging houses that charge fees.

The imposition of hotel tax is not absolute in all regencies or cities in Indonesia. this matter, relates to the authority granted to district or city governments to impose or not to wear a 
type of district or city tax. Therefore, to be collected in a district or city, the regional government must first issue regional regulations on hotel taxes. The regulation will become an operational legal basis in the technical implementation of the imposition and collection of hotel tax in the relevant regency or city area. The legal basis for collecting hotel taxes in a district or city is as below:

1) Law of The Republic Indonesia Number 34 Year 2000 which is a change to Law of The Republic Indonesia Number 18 Year 1997 concerning Local Taxes and Retributions

2) Government Regulation Number 65 Year 2001 about Local Taxes

3) Regional Regulation of Manado City Number 2 Year 2011 about Local Taxes

Consumers who enjoy hotel services are tax subjects who pay (bear) taxes, while hoteliers act as taxpayers who are authorized to collect taxes from consumers (tax subjects) and carry out other tax obligations. The basis for imposing hotel tax is the amount of payment made to the hotel. Payment is the amount of money to be paid by the tax subject to the taxpayer for the selling price of both the amount paid and the replacement that should be requested by the taxpayer as an exchange for the use of lodging services and supporting facilities including all additional names whatever are related to hotel business. Hotel tax rates apply at a maximum of ten percent and are determined by the relevant regency/city regulations. Manado City Hotel tax rate of $10 \%$ In accordance with Manado City Regional Regulation No. 2 of 2011 concerning Regional taxes. The amount of the hotel tax payable is calculated by multiplying the tax rate on the basis of taxation. According to the Regional Regulation of Manado City No. 2 of 2011 in Chapter I Article 1 Paragraph 13 Restaurants are facilities for providing food and/or drinks with a fee, which includes restaurants, cafeterias, canteens, stalls, bars and the like including catering/catering services. Restaurant tax is a tax on services restaurant. Restaurant tax collection in the city of Manado is currently based on Manado City Regional Regulation No. 2 of 2011. Restaurant tax imposition is not absolute in all regencies or cities in Indonesia. this matter, relates to the authority granted to district or city governments to impose or not to wear a type of district/city tax. Restaurant tax collection is carried out by the Manado City Government based on legal sources, including: Law of The Republic Indonesia Number 10 of 2008 concerning Regional Government, Law of The Republic Indonesia No. 33 of 2004 concerning Financial Balance between Central and Regional Governments. The restaurant tax object is a service provided by a restaurant with payment.

The services provided by the Restaurant include the service of selling meals and/or drinks consumed by the buyer, both consumed at the place of service and elsewhere. Simply put, the subject of tax is consumers who enjoy and pay for services provided by restaurant entrepreneurs. Meanwhile, those who become taxpayers are restaurant entrepreneurs, namely people who are individuals or entities in any form who are in the company or work in the restaurant sector.

Consumers who enjoy restaurant services are tax subjects who pay (bear) taxes while restaurant entrepreneurs act as taxpayers who are authorized to collect taxes from consumers (tax subjects). The basis for imposing restaurant tax is the amount of payment made to the restaurant. Payment is the amount of money that must be paid by the tax subject to the taxpayer for the selling price of both the amount paid and the replacement that should be requested by the taxpayer as an exchange for the purchase of food and/or drinks, including any additional names also made in connection with the restaurant business.

The restaurant tax rate is set at a maximum of ten percent and is determined by the relevant regency/city regulations. This is intended to provide flexibility to the district/ city government to set tax rates that are deemed in accordance with the conditions of each district/city. Thus, each district/city is given the authority to set a tax rate that may be different from other districts/cities, provided there is no more than $10 \%$. According to Abdul Halim (2004: 163) the contribution of hotel and restaurant tax revenues to local revenue can be measured by comparing between the realiza- 
tion of restaurant tax revenue and the realization of own source revenue. This is similar to what Nugroho Budiyuwono (1995: 160) stated.

This comparison can be formulated as follows:

$P n=\frac{\text { Total of Restaurant Tax Receipt }}{\text { Total of Own Source Revenue }} \times 100 \%$

Description :

Pn : Contribution of hotel and restaurant tax to own source revenue (Rupiah)

Qx : Total of Restaurant tax receipt (Rupiah)

Qy : Total of Own Source Revenue (Rupiah)

$\mathrm{n}$ : Certain years (periods)

$\begin{array}{lccl} & \text { Percentage } & \text { Criteria } & \text { Contributions: } \\ \text { 1. } & 0 \% & -10 & \text { is very less } \\ \text { 2. } & 11 \% & -20 \% & \text { less } \\ \text { 3. } & 21 \% & -30 \% & \text { medium } \\ \text { 4. } & 31 \% & -40 \% & \text { moderate enough } \\ 5 . & 41 \% & -50 \% & \text { good } \\ 6 . & \text { Above } & 50 \% & \text { very good }\end{array}$

Source : Litbang Depdagri-Fisipol UGM, 1991 (in Handoko:2013)

Effectiveness is a balance between actual income and potential income from a tax with a budget that should be paid, actually fulfilling its obligations. Effectiveness is used to measure the relationship between the results of levies on a tax and the real goals or potential that an area has.

If the concept of effectiveness is associated with restaurant tax revenue, the effectiveness in question is how much the realization of restaurant tax revenue reaches the target that should be achieved in a certain period (Halim, 2001: 158). Effectiveness describes the ability of local governments to realize restaurant taxes budgeted compared to targets set based on the real potential of the region. The effectiveness of measuring output levels against expected targets. Therefore measurement of effectiveness requires data on realization of income and budget or revenue target. According to Mohamad Mahsum (2006: 187) the formula for measuring effectiveness is as follows:

Measurement of Effectiveness Level:

$$
\text { Effectiveness Level }=\frac{\text { Realized } \text { Revenue }}{\text { Revenue } \text { Budget }} \times 100 \%
$$

With the above calculations, it can be seen the effectiveness of Restaurant Tax management, assuming that the greater the effectiveness obtained, the higher the level of effectiveness. Thus, the greater the effectiveness shows the more effective collection activities. That is, the greater the ability to collect it and the purpose of collection activities is getting closer to being achieved (Prakosa Kesit Bambang, 2005: 144).

Tabel 2 Effectiveness Percentage Criteria

\begin{tabular}{cll}
\hline No. & Effectiveness Percentage & Description \\
\hline 1. & $>100 \%$ & Very Effective \\
\hline 2. & $>90 \%-100 \%$ & Effective \\
\hline 3. & $>80 \%-90 \%$ & Effective enough \\
\hline 4. & $>60 \%-80 \%$ & Less Effective \\
\hline 5. & $<60 \%$ & Not effective \\
\hline
\end{tabular}

Source: Emidayenti (2008:50)

\section{Method}

In accordance with the problem This type of research is a qualitative descriptive study the result is a complete picture and data collection is based on the object of research, the results are only valid for the object under study and the conclusions cannot be generalized. The study was conducted at the Tax Revenue and the Retribution of Manado City. With the technique of collecting data through interviews, literature studies and documentation. This research uses contribution analysis which is used to find out how much contribution that can be 
contributed from hotel and restaurant tax receipts to the receipt of Own Source Revenue in the City of Manado, so that it is compared between the realization of hotel and restaurant tax revenues towards OSR.

\section{Result and Discussion}

Realization of Tax and Restaurant Revenues for 3 consecutive years can be seen in table 3 below.

Table 3. Realization of Hotel and Restaurant Tax Revenues, Total of Hotels and Restaurants, Inflation Rate and Total of tourists in 2014-2016.

\begin{tabular}{cccccccc}
\hline \multirow{2}{*}{ No } & \multirow{2}{*}{ Year } & \multicolumn{2}{c}{ Taxes } & \multicolumn{2}{c}{ Total } & \multirow{2}{*}{ TI (\%) } & \multirow{2}{*}{ JW (Person) } \\
\cline { 3 - 5 } & & Hotel & Restaurant & Htl. & Rst. & & \\
\hline 1 & 2014 & 17.449 .408 .116 & 40.401 .504 .799 & 104 & 98 & 9,67 & 866.458 \\
\hline 2 & 2015 & 18.168 .799 .451 & 47.469 .492 .846 & 125 & 79 & 5,56 & 1.109 .081 \\
\hline 3 & 2016 & 25.425 .453 .862 & 60.607 .630 .932 & 177 & 142 & 0,35 & 1.274 .168 \\
\hline
\end{tabular}

Source: Badan Pusat Statistik of Manado City

The development of hotel and restaurant tax realization from year to year can be said to experience continuous improvement. This is because, due to the increasing number of tourists visiting tourist attractions in the city of Manado which has an impact on the number of visitors to hotels and restaurants. The development of the number of hotels in the city of Manado is relatively stable while the restaurants are volatile because in Manado City most of them are restaurants or food stalls that are very vulnerable to the economic conditions of the people of Manado City. The number of tourists visiting tourist attractions in the city of Manado from year to year tends to increase, this is due to the addition of objects and improvements made by the management of tourist objects and the people who began to appreciate tourism activities as one of the needs to eliminate the feeling saturation. The contribution of hotel and restaurant taxes to Regional Original Income (PAD) in Manado City is calculated by comparing the amount of hotel and restaurant tax receipts with the Own Source Revenue (OSR) receipts. The amount of the contribution can be seen in Table 4 and Table 5.

Table 4. Contributions of Hotel Taxes to Local Tax Revenues and 2014-2016 OSR of Manado City

\begin{tabular}{cccccc}
\hline & \multicolumn{3}{c}{ Realization of Receipt (Rp) } & \multicolumn{2}{c}{ Contribution (\%) } \\
\cline { 2 - 6 } Year & Hotel Taxes & Local Taxes & $\begin{array}{c}\text { Own Source } \\
\text { Revenue }\end{array}$ & $\begin{array}{c}\text { Local } \\
\text { Taxes }\end{array}$ & $\begin{array}{c}\text { Own Source } \\
\text { Revenue }\end{array}$ \\
\hline 2014 & 17.449 .408 .116 & 87.303 .746 .686 & 263.392 .296 .958 & $5,33 \%$ & 6,62 \\
2015 & 18.168 .799 .451 & 05.090 .034 .810 & 289.462 .741 .463 & $8,85 \%$ & 6,27 \\
2016 & 25.425 .453 .862 & 222.234 .798 .430 & 306.453 .382 .648 & $11,44 \%$ & 8,29 \\
\hline
\end{tabular}

Source: Data Olahan, 2018

Table 5. Restaurant Tax Contributions to Local Tax Receipts and Own Source Revenue of Manado City for the Period of the 2014-2016 Budget Year

\begin{tabular}{cccccc}
\hline \multirow{2}{*}{ Year } & \multicolumn{3}{c}{ Realization of Receipt (Rp) } & \multicolumn{2}{c}{ Contribution (\%) } \\
\cline { 2 - 6 } & $\begin{array}{c}\text { Restaurant } \\
\text { Taxes }\end{array}$ & Local Taxes & $\begin{array}{c}\text { Own Source } \\
\text { Revenue }\end{array}$ & $\begin{array}{c}\text { Local } \\
\text { Taxes }\end{array}$ & $\begin{array}{c}\text { Own Source } \\
\text { Revenue }\end{array}$ \\
\hline 2014 & 40.401 .504 .799 & 187.303 .746 .686 & 263.392 .296 .958 & $21,57 \%$ & $15,33 \%$ \\
2015 & 47.469 .492 .846 & 205.090 .034 .810 & 289.462 .741 .463 & $23,14 \%$ & $16,57 \%$ \\
2016 & 60.607 .630 .932 & 222.234 .798 .430 & 306.453 .382 .648 & $27,27 \%$ & $19,77 \%$ \\
\hline
\end{tabular}

Source: Data Olahan, 2018 
Calculation of Restaurant Tax Contributions to Own Source Revenue:

$$
\begin{aligned}
& \text { Year } 2014=\frac{40.401 .504 .799}{263.392 .296 .958} \times 100 \%=15,33 \% \\
& \text { Year } 2015=\frac{47.469 .492 .846}{289.462 .741 .463} \times 100 \%=16,57 \% \\
& \text { Year } 2016=\frac{60.607 .630 .932}{306.453 .382 .648} \times 100 \%=19,77 \%
\end{aligned}
$$

Based on the results of the above calculations, the amount of the contribution of hotel and restaurant taxes to Manado City's Own Source Revenue for the fiscal year 2002-2016 varies from $6.27 \%$ to $19.77 \%$. The increase in hotel and restaurant tax contributions is due to the number of hotels and restaurants and due to the number of visits to hotels and restaurants. The hotel tax contribution in 2014 amounted to $6.62 \%$, then decreased by $0.35 \%$ to $6.27 \%$ in 2015 , this decrease was caused by a lack of awareness of taxpayers on the interests of paying taxes and lack of socialization from the government or related agencies managing taxes and weak government regulations so that they are easily violated. The biggest hotel tax contribution occurred in 2016 with an increase of $2.02 \%$ to $8.29 \%$. Based on the results of the above calculation, the hotel tax contribution to the Own Source Revenue of Manado City fluctuates. In 2014 the restaurant tax contribution amounted to $15.33 \%$. In 2015 , there was an estimated $1.24 \%$ to $16.56 \%$, and the biggest restaurant tax contribution occurred in 2016 with an increase of $3.21 \%$ to $19.77 \%$. This increase occurred due to the large number of visitors and the growth rate of restaurants in the city of Manado in 2016. Even though the achievement of Hotel and Restaurant Tax Contributions in Manado City is still relatively small, it is quite significant in financing government administration. And based on the research studied, Hotel and Restaurant Taxes have a very small influence on the Own Source Revenue of Manado City.

Hotel Tax Contribution Calculation for Local Taxes:

$$
\begin{aligned}
& \text { Year } 2014=\frac{17.449 .408 .116}{187.303 .746 .686} \times 100 \%=9,31 \% \\
& \text { Year } 2015=\frac{18.168 .799 .451}{205.090 .034 .810} \times 100 \%=8,85 \% \\
& \text { Year } 2016=\frac{25.425 .453 .862}{222.234 .798 .430} \times 100 \%=11,44 \%
\end{aligned}
$$

Calculation of Restaurant Tax Contributions to Local Taxes:

$$
\begin{aligned}
& \text { Year } 2014=\frac{40.401 .504 .799}{187.303 .746 .686} \times 100 \%=21,57 \% \\
& \text { Year } 2015=\frac{47.469 .492 .846}{205.090 .034 .810} \times 100 \%=23,14 \% \\
& \text { Year } 2016=\frac{60.607 .630 .932}{222.234 .798 .430} \times 100 \%=27,27 \%
\end{aligned}
$$

Based on the results of the above calculations, it can be seen that the Local Tax from Hotel Taxes during 2014-2016 contributed up and down or fluctuated. In 2014 the hotel tax contribution to local taxes amounted to $15.33 \%$, but in 2015 its contribution decreased 6.48\% to $8.85 \%$. Then in 2016 rose by $2.59 \%$ to $11.44 \%$. This decline occurred because the number of hotel visitors decreased. Then the Local Tax Revenues from Restaurant Taxes during 2014-2016 continued to increase com- 
pared to Restaurant tax. In 2014 the contribution of restaurant tax to local taxes amounted to $21.57 \%$, then rose $1.57 \%$ in 2015 to $23.14 \%$. In 2016 it rose again by $4.13 \%$ to $27.27 \%$ and it can be said that in 2016 it was the highest achievement. In this study, which was considered in determining effectiveness was only the achievement of targets.

Table 6. Tax Effectiveness of Manado City Hotels for Budget Year of 2014-2016

\begin{tabular}{cccccc}
\hline Number & Year & $\begin{array}{c}\text { Hotel Tax of } \\
\text { Target }\end{array}$ & $\begin{array}{c}\text { Tax Realization of } \\
\text { Hotels }\end{array}$ & $\begin{array}{c}\text { Hotel Tax of } \\
\text { Effectiveness }\end{array}$ & Interpretation \\
\hline 1 & 2014 & 15.999 .999 .900 & 17.449 .408 .116 & $109,05 \%$ & very effective \\
2 & 2015 & 18.000 .000 .000 & 18.168 .799 .451 & $100,93 \%$ & very effective \\
3 & 2016 & 20.900 .000 .000 & 25.425 .453 .862 & $121,65 \%$ & very effective \\
\hline
\end{tabular}

Source : Data Olahan, 2018

Table 7. Manado City Restaurant Tax Effectiveness for Bugdet Year of 2014-2016

\begin{tabular}{cccccc}
\hline Number & Year & $\begin{array}{c}\text { Hotel Tax of } \\
\text { Target }\end{array}$ & $\begin{array}{c}\text { Tax Realization } \\
\text { of Hotels }\end{array}$ & $\begin{array}{c}\text { Restaurant Tax } \\
\text { of Effectiveness }\end{array}$ & Interpretation \\
\hline 1 & 2014 & 38.550 .000 .000 & 40.401 .504 .799 & $104,80 \%$ & very effective \\
2 & 2015 & 42.000 .000 .000 & 47.469 .492 .846 & $113,02 \%$ & very effective \\
3 & 2016 & 47.500 .000 .000 & 60.607 .630 .932 & $127,59 \%$ & very effective \\
\hline
\end{tabular}

Source : Data Olahan, 2018

$$
\text { Effectiveness }=\frac{\text { Realization Receipt of Hotel Tax Revenue } \text { or Restaurant }}{\text { Hotel Tax and Restaurant Receipt of Target }} \times 100 \%
$$

Calculation of Hotel Tax Effectiveness Level in Manado City Year 2014-2016:

$$
\begin{aligned}
& \text { Year } 2014=\frac{17.449 .408 .116}{15.999 .999 .900} \times 100 \%=109,05 \% \\
& \text { Year } 2015=\frac{18.168 .799 .451}{18.000 .000 .000} \times 100 \%=100,93 \% \\
& \text { Year } 2016=\frac{25.425 .453 .862}{20.900 .000 .000} \times 100 \%=121,65 \%
\end{aligned}
$$

Calculation of Restaurant Tax Effectiveness Level in Manado City Year 2014-2016:

$$
\begin{aligned}
& \text { Year } 2014=\frac{17.449 .408 .116}{15.999 .999 .900} \times 100 \%=104.80 \% \\
& \text { Year } 2015=\frac{18.168 .799 .451}{18.000 .000 .000} \times 100 \%=113,02 \% \\
& \text { Year } 2016=\frac{25.425 .453 .862}{20.900 .000 .000} \times 100 \%=127,59 \%
\end{aligned}
$$

From the results of the calculation above, it can be said that the effectiveness of the hotel and restaurant tax in Manado City in 2014 to 2016 has fluctuated. In 2014 the hotel tax effectiveness was $109.05 \%$, then the hotel tax effectiveness rate decreased by $8.12 \%$ to $100.93 \%$ in 2015 . In 2016 it rose $21.72 \%$ to $121.65 \%$. The increase in the level of effectiveness shows that the performance in collecting hotel taxes increases even better. In contrast to the effectiveness of restaurant taxes, in 2014 the restaurant tax effectiveness was $104.80 \%$, then increased by $8.22 \%$ to $113.02 \%$ in 2015 . In 2016 the restaurant tax effectiveness rate rose again by $14.57 \%$. This proves that the government has made efforts to increase the progress of restaurant tax collection. The effectiveness of restaurant tax collection does not show progress in terms of fluctuating runs from year to 
year for hotel taxes while restaurant taxes provide an increase every year. Based on the research carried out the realization of the hotel tax each year exceeds the target. However, the contribution given by the hotel tax changes or fluctuates annually. Realization of restaurant tax every year has increased and every year always gives an increasing contribution to local revenue. Although restaurant tax contributions always increase every year, restaurant tax contributions do not have a large influence on Manado City's Own Source Revenue during 20142016.

Table 8. Total of Hotels and Restaurants, Travelers, Hotel and Restaurant Tax Contributions and Effectiveness for 2014-2016

\begin{tabular}{cccccccc}
\hline \multirow{2}{*}{ Year } & Total & Total & Total & \multicolumn{2}{c}{ Contributios } & \multicolumn{2}{c}{ Effectiveness } \\
& Hotel & Restaurant & Tourists & Htl. & Rst. & Htl. & Rst. \\
\hline 2014 & 104 & 98 & 866.458 & 6,62 & $15,33 \%$ & $109,05 \%$ & $104,80 \%$ \\
2015 & 125 & 79 & 1.109 .081 & 6,27 & $16,57 \%$ & $100,93 \%$ & $113,02 \%$ \\
2016 & 177 & 142 & 1.274 .168 & 8,29 & $19,77 \%$ & $121,65 \%$ & $127,59 \%$ \\
\hline
\end{tabular}

Source : 2018

Based on the results of the research above the percentage of the contribution and effectiveness of hotel taxes during 2014-2016 has fluctuated or fluctuated. In 2014 Hotel Taxes gave a high percentage of Contributions and Effectiveness for Own Source Revenues. But in 2015 , it was clearly seen in the decrease in the percentage of contributions and effectiveness of hotel taxes. If examined in more detail, the number of hotels and tourists in 2015 tends to keep up, but the contribution and effectiveness of hotel taxes has declined. This decrease in percentage is no longer recognized by the declining number of hotels and tourists, but the reduced awareness of paying taxes from taxpayers, lack of socialization of the importance of paying taxes to taxpayers as well as weak sanctions and regulations given by the government so that taxpayers tend to ignore their responsibilities as a taxpayer. In 2016 the presentation of contributions and effectiveness surged again.

This is due to the government's enthusiasm in disseminating the interest in paying taxes in the City of Manado. The Percentage of Restaurant Tax Contributions and Effectiveness is very different from hotel taxes. If the percentage of contribution and effectiveness of hotel tax experiences fluctuations or ups and downs, it is very different from the percentage given by restaurant tax. During 2014-2016 restaurant taxes always provide a percentage of contribution and increased effectiveness for Own Source Revenue. This is because taxpayers or managers of restaurants have a high awareness of the importance of paying taxes every year, so the restaurant tax in the city of Manado.

\section{Conclusion}

Factors that influence Hotel and Restaurant Tax Revenue, Total of Hotels and Restaurants, This shows that the number of hotels and restaurants is also a leading indicator that plays a major role in regional revenues, especially hotel and restaurant tax revenues. If hotels and restaurants increase, then hotel and restaurant tax receipts will increase as well, thus increasing Own Source Revenue, Total of Tourists, this indicates the Manado City Government must pay attention to tourist attractions in the city of Manado.

Due to the existence of tourist attractions, the number of both local and foreign tourists coming in Manado will increase and the number of tourists who will stay in hotels and also will eat in restaurants will increase and will affect the hotel and restaurant tax revenues increasingly, regulations Hotel and Restaurant Tax, regarding hotel and restaurant tax regulations, whether the tax object, tax subject, tax collection procedures etc., in Manado City are clearly set in the Regional Regulation of Manado City Number 2 of 2011 concerning Regional Taxes, Knowledge of the community on payment of taxes. The level of knowledge of the people in the City of Manado will be the regulations that regulate taxes are still very lacking due to the lack of socialization from tax officers. 


\section{References}

Bawasir, Fuad. 1999. Kontribusi dan Efektivitas. (http//ejournal.unud.ac.id; diakses 7 Maret 2018).

Bellinda.K 2016, Analisis Kontribusi Pajak Restoran Terhadap Pendapatan Asli Daerah Kabupaten Minahasa.

Budiyuwono, Nugroho. 1995. Pengantar Statistik Ekonomi dan Perusahaan, UPP AMP.

Christina.P 2010, Analisis Kontribusi Pajak Hotel dan Restoran Terhadap Pendapatan Asli Daerah Pemerintah Kota Yogyakarta.

D. Tyasari.K 2012, Analisis Kontribusi Pajak Hotel dan Restoran Terhadap Penerimaan Pendapatan Asli Daerah Kabupaten Tegal

Dwi Prastowo dan Rafika Julianti, 2002, Analisis Laporan Keuangan (Konsep dan Aplikasi), Edisi Revisi, Ypgyakarta : YPKN.
Harahap, Sofyan Syafri. (2004). Analisis Krisis atas Laporan Keuangan. Jakarta: Rajawali Pers.

Halim, Abdul dan Damayanti, Theresia. 2007. Pengelolaan Keuangan Daerah. Edisi Kedua. Yogyakarta: UPP STIM YKPN.

Peraturan Daerah Kota Manado Tahun 2011 Nomor 2.

Undang-undang Nomor 12 Tahun 2008 atas perubahan Undang-undang Nomor 32 Tahun 2004 tentang Pemerintahan Daerah.

Undang-undang Nomor 28 Tahun 2009 Tentang Pajak Daerah Dan Retribusi Daerah.

Undang-undang Nomor 34 Tahun 2000 yang merupakan perubahan atas Undang Undang Nomor 18 Tahun 1997 tentang Pajak Daerah dan Retribusi Daerah 